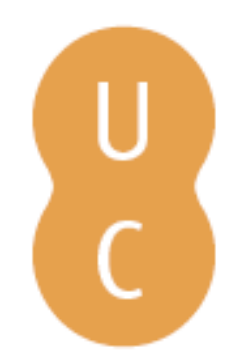

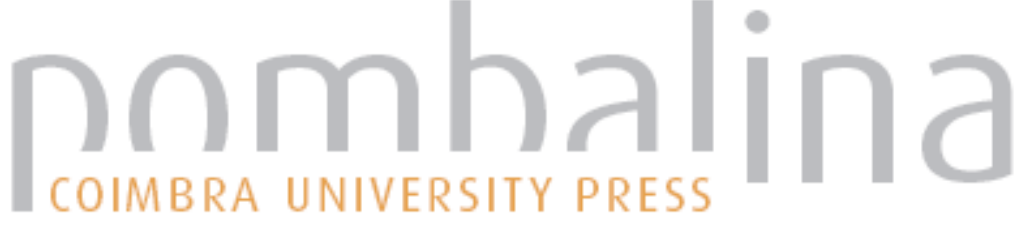

\section{Moçambique cinematográfico: a terceira margem}
Autor(es):
Azevedo, Licinio de
Publicado por: Imprensa da Universidade de Coimbra
URL
persistente:
URl:http://hdl.handle.net/10316.2/43875
DOI:
DOI:https://doi.org/10.14195/978-989-26-1395-6_4

Accessed : $\quad$ 26-Apr-2023 12:21:05

A navegação consulta e descarregamento dos títulos inseridos nas Bibliotecas Digitais UC Digitalis, UC Pombalina e UC Impactum, pressupõem a aceitação plena e sem reservas dos Termos e Condições de Uso destas Bibliotecas Digitais, disponíveis em https://digitalis.uc.pt/pt-pt/termos.

Conforme exposto nos referidos Termos e Condições de Uso, o descarregamento de títulos de acesso restrito requer uma licença válida de autorização devendo o utilizador aceder ao(s) documento(s) a partir de um endereço de IP da instituição detentora da supramencionada licença.

Ao utilizador é apenas permitido o descarregamento para uso pessoal, pelo que o emprego do(s) título(s) descarregado(s) para outro fim, designadamente comercial, carece de autorização do respetivo autor ou editor da obra.

Na medida em que todas as obras da UC Digitalis se encontram protegidas pelo Código do Direito de Autor e Direitos Conexos e demais legislação aplicável, toda a cópia, parcial ou total, deste documento, nos casos em que é legalmente admitida, deverá conter ou fazer-se acompanhar por este aviso.

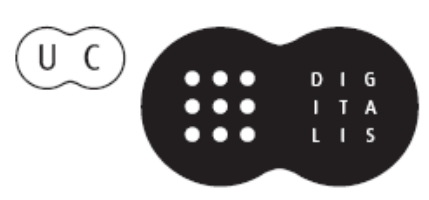



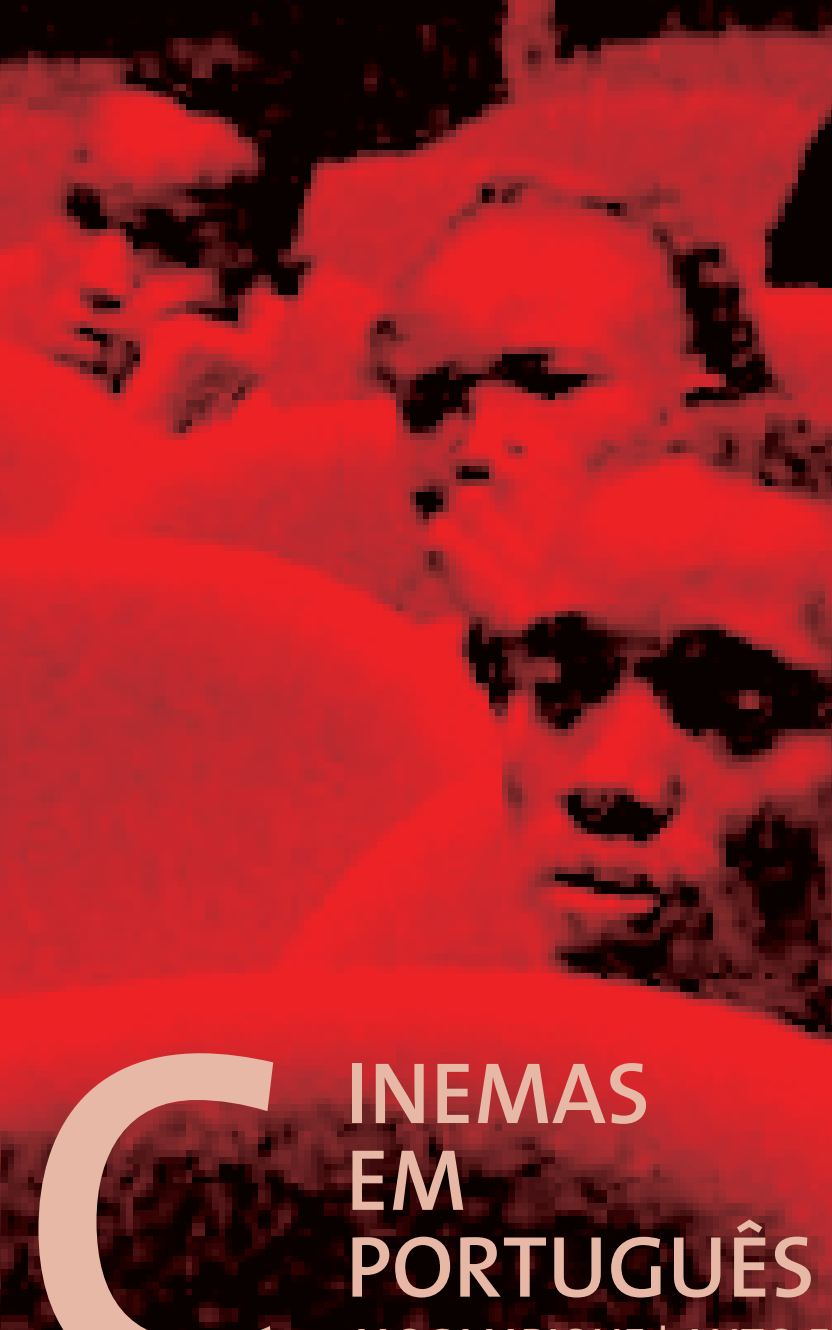

INEMAS

EM

PORTUGUÊS

MOÇAMBIQUE | AUTO E HETEROPERCEÇÕES

JORGE SEABRA

COORDENAÇÃO 


\section{O ÇAMB I Q U E C I N EMATOGRÁFICO.}

\section{A TERCEIRA MARGEM}

Licinio de Azevedo Realizador | Produtor

Há cerca de 40 anos, antes de mudar-me para Moçambique, o que era o continente africano para mim? Era, basicamente, desde a minha juventude, as minhas leituras de Hemingway: As Verdes Colinas da África, As Neves do Kilimanjaro... Era, também, um outro lado da realidade que eu conhecera como jornalista num país dominado pela censura, o Brasil da época, onde era proibido referir-se a nomes como Amilcar Cabral, Agostinho Neto, Samora Machel que vinham nos despachos das agências internacionais de informação. Portanto, ao chegar a Moçambique, eu conhecia também o lado das guerras travadas pela independência dos nossos países irmãos. O que eu não conhecia era "a terceira margem do rio": o lado mágico da realidade, o lado espiritual.

Logo a seguir à minha chegada, como jornalista e escritor, pois ainda nem sequer pensava em fazer cinema, no meu primeiro trabalho, nas antigas zonas libertadas, no Planalto de Mueda, onde devia recolher relatos sobre a guerra, quis fazer jus ao meu velho mestre Hemingway. O planalto era uma zona rica em caça. Conseguimos uma arma e numa noite, com um guia da aldeia onde estávamos hospedados, eu e os meus colegas moçambicanos saímos para o mato. Andámos toda a noite e parte do dia seguinte e não encontrámos nenhum animal. Voltámos para a aldeia completamente frustrados. Então, ali, comecei DOI: https://doi.org/10.14195/978-989-26-1395-6_4 
a descobrir o lado da África no qual Hemingway nunca tocou nos seus livros, porque ele só falava do bwana, do grande caçador branco. Pedi explicações ao guia: "Como foi possível não vermos um único animal?" Ele respondeu: "Eu acho que sei". E perguntou-me: "Levou algum dinheiro no bolso?" Eu disse: "Sim, sempre levo dinheiro no bolso". Ele ficou chateado: "Levou dinheiro lá para o mato!?" "Sim". "É por isso que os animais não apareceram. Nenhum caçador pode levar dinheiro para o mato, os animais não aparecem".

Sem prejudicar o lado político e social do trabalho que eu fazia, esse lado mágico das coisas passou a fazer parte dele. E tornou-se muito forte quando comecei a fazer filmes e mergulhei com o espírito aberto nas estórias que surgiam à minha frente, por todo o país. Na verdade, rendi-me à evidência dessa realidade mágica, pois mesmo sendo mágica não deixa de ser realidade e que foi possivelmente o meu passaporte para o cinema.

As pessoas passaram a gostar do meu trabalho, os moçambicanos, porque ele refletia, além dos aspetos sociais, também esses aspetos fundamentais nas suas vidas, que são as suas crenças, e que normalmente eram ignoradas ou mesmo condenadas no nosso dito cinema revolucionário dos anos pós-independência ou folclorizados e deturpados num outro tipo de cinema. Para mim o "Moçambique cinematográfico" inclui obrigatoriamente esta parte muito rica da nossa realidade, não como mero exercício estético, intelectual, mas como uma integração verdadeira e espiritual.

Posso dar, no meu trabalho, e os meus colegas poderão dar no deles, muitos exemplos do que estou a falar. Num dos meus primeiros documentários importantes, A Árvore dos Antepassados, e o título já diz tudo, a história tem como centro a necessidade dos refugiados de guerra moçambicanos que estiveram dez anos no Malawi de, ao regressarem, se reconciliarem com os seus antepassados, através das cerimónias próprias. Quando uma pessoa viaja tem que se despedir dos antepassados, junto à árvore que os representa. Durante a guerra, 
ao fugirem, não tiveram hipótese alguma de fazê-lo. No documentário eu segui a viagem de regresso de uma família de um centro de refugiados no Malawi até a sua zona de origem, uma viagem que levou mais de um mês, num cenário de destruições causadas pela guerra. O filme acaba exatamente debaixo de uma árvore, no reencontro da família com os seus antepassados, para apresentar os filhos e netos que nasceram longe de casa. É um filme muito emotivo, as pessoas geralmente choram no final, e eu também.

Talvez tenha sido ao fazer esse filme que Steinbeck, com o seu romance A um Deus Desconhecido, passou a ter para mim a mesma preponderância que Hemingway como influência literária. E Steinbeck era um homem muito relacionado com as causas sociais, basta citar o seu livro As Vinhas da Ira, filme de John Ford, com Henry Fonda. Ele foi carpinteiro, operário, marinheiro... Em plena América escreveu um romance em que os antepassados são homenageados junto a uma árvore, tal como em África.

Em Mariana e a Lua deparei-me com outra história exemplar. O documentário é sobre a viagem aos Estados Unidos de Mariana Mpande, uma curandeira e líder comunitária de Tchuma Tchato, uma zona muito isolada, na fronteira de Moçambique com a Zâmbia e o Zimbabwe. A ida aos Estados Unidos era para encontrar-se com curandeiros e líderes espirituais locais, representantes de índios, um curandeiro do Havai... Luciano, o maior caçador de Tchuma Tchato, deveria acompanhá-la. Eu o havia escolhido por conhecê-lo de um outro documentário feito dois anos antes na mesma comunidade. Luciano tinha poderes mágicos, que eu próprio e a equipe que filmava comigo constatámos. Diziam que ao caçar ele tornava-se invisível ou se transformava numa árvore, numa pedra, e os animais se aproximavam dele sem nenhum receio e ele podia escolher calmamente a melhor presa e abatê-la. Infelizmente ele não pôde fazer a viagem por ter feito uma outra pouco antes, definitiva: foi morto por um poderoso feiticeiro malawiano, contratado para isso por um caçador mais fraco e que 
invejava os seus poderes. Como eu dizia, no documentário anterior conheci o "caçador mágico". Estávamos a filmar numa aldeia e ela é invadida por uma manada de elefantes furiosos que investiu contra os moradores e a nossa equipe, causando pânico e ameaçando vidas, sem que houvesse maneira de afugentá-los. Luciano surge em meio aos elefantes e calmamente os conduz para fora da aldeia, como se aqueles animais furiosos fossem inofensivos cabritos e ele o seu pastor.

No filme que vou fazer agora, O Comboio de Sal e Açúcar, uma ficção, um dos personagens principais, o comandante Sete Maneiras, é inspirado em Manuel António, líder dos Naparamas. Os Naparamas, que surgiram durante a guerra civil e apoiavam o exército governamental, eram uns vinte ou trinta mil homens que combatiam nús, empunhando apenas armas tradicionais, arco, flechas e lanças. Eram invulneráveis, à prova de balas, e o inimigo fugia à sua aproximação, sem sequer tentar combatê-los. Isto durou até o momento em que Manoel António foi morto, com mais de cem balas. Claro, houve uma explicação para esta ocasional vulnerabilidade. Havia algumas regras a serem cumpridas antes de um combate. Os naparamas não podiam comer comida com sal, nem manter relações sexuais. Dizem que ele foi seduzido por uma bela feiticeira enviada pelo inimigo e fez sexo com ela no período proibido.

Tudo isto, para mim, é uma parte fundamental do "Moçambique cinematográfico". Quem não acredita que o crocodilo que ataca uma pessoa na beira de um rio foi enviado por alguém, não mergulhou nesta realidade e não pode fazer filmes em Moçambique. Quem não acredita que os crocodilos raptam pessoas e as levam para ilhas para trabalharem para eles em machambas secretas, não pode fazer filmes em Moçambique. Quem não acredita que os feiticeiros à noite cavalgam hipopótamos no meio dos rios, também não, porque não conhece a terceira margem desses rios. Num outro episódio, num céu completamente azul, surgiu uma nuvenzinha escura e dela saiu um raio que matou duas irmãs numa aldeia. $\mathrm{O}$ raio foi enviado, obviamente. 
Há outros aspetos do "Moçambique cinematográfico", em que a magia não entra, mas neste Simpósio tive a sorte de poder falar antes dos meus colegas e deixo para eles a tarefa árdua de falar dessa realidade mais dura. Vou referir-me apenas a uma situação complexa em que me vi envolvido na filmagem de um documentário-ficção, ou ficção-documentário, Desobediência, que fiz numa zona bastante isolada no centro do país, e que se aproxima de uma tragédia grega. Encontrei o tema na leitura de jornais, a história de uma homem que se suicidara alegando que a esposa era desobediente, recusava-se até mesmo a preparar a água para o seu banho. Fiz a pesquisa entrevistando todos os envolvidos no drama e descobri um outro "guião". A família do morto culpava a viúva para poder se apossar dos bens do casal, a palhota, uns poucos cabritos e galinhas e, sobretudo, ficar com os seus cinco filhos, ainda crianças mas já de grande ajuda nas machambas familiares. Convenci todos a representarem os seus próprios papeis no filme que reproduziria os acontecimentos. O suicida tinha um irmão gémeo e este teria um duplo papel: o seu e o do falecido. As filmagens, já no seu fim, incluiam a consulta a um curandeiro, com todos presentes, para que ele, especialista em casos que envolvem mortes, indicasse o culpado, tal como fora feita meses antes, quando os fatos ocorreram, e cujo desfecho eu desconhecia. Tudo decorreu como se fosse a primeira consulta, absolutamente verdadeira, a transfiguração do curandeiro, a presença do espírito do morto, as reações dos familiares. E só no seu desfecho eu me dei conta de que filmava algo que me transportava para Édipo, Electra, mas absolutamente real. Um tabú fora quebrado. As tradições locais interditam um homem de fazer amor com a mulher do seu irmão gémeo. O nosso suicida fizera e isto causou a sua morte.

As pessoas filmadas em Desobediência não tinham acessso à televisão, nunca tinham visto cinema. Para levar a viúva a abandonar a sua machamba e trabalhar connosco nas seis semanas necessárias, a produção do filme pagou-a com um carro de bois, uma junta de 
bois, uma charrua e construiu-lhe uma casa de blocos, longe de onde vivia a família do marido. Meses depois, quando passei pela zona, para um outro trabalho, parei para visitá-la. A minha presença alterou completamente a rotina familiar da viúva. Ela chamou os cinco filhos, deu-lhes banho, juntou as suas roupas, reuniu os vizinhos e começou a leiloar todos os seus bens. Eu não falava a língua e estava com dificuldade para comprender o que se passava. Até que alguém me explicou: ela pensava que o que recebeu da produção do filme era o lobolo (dote) que eu havia pago para casar com ela. Estava pronta para seguir-me com os filhos para irem viver comigo na cidade. Ao saber disto, parti sem me despedir. E até hoje, passados mais de dez anos, evito aquela zona. 